\title{
Studies on the Biosynthesis of Bacterio-opsin
}

\author{
Demonstration of the Existence \\ of Protein Species Structurally Related to Bacterio-opsin
}

Manfred SUMPER and Gisela HERRMANN

Institut für Biochemie der Universität Würzburg

(Received April 24, 1978)

1. The kinetics of processing newly synthesized bacterio-opsin from the non-crystalline state within the brown membrane to the crystalline state within the purple membrane was followed by pulse-chase experiments.

2. Biosynthesis of bacterio-opsin was found to be highly resistant to RNA-synthesis inhibitors like rifampicin and ethidium bromide. In the presence of ethidium bromide, only five protein species continue to be synthesized in halobacteria, one of them being bacterio-opsin.

3. In spheroplasts, synthesis of bacterio-opsin is found to be selectively disturbed. The purple membrane isolated from spheroplasts contains new, additional protein species with apparent molecular weights of 19000,23000 and 29000 . These proteins share common amino acid sequences with bacterio-opsin.

4. In the halobacterial cell membrane, two membrane proteins with apparent molecular weights of 30000 and 36000 were detected which are structurally related to bacterio-opsin.

5. Bacterio-opsin as well as the $30000-M_{\mathrm{r}}$ and $36000-M_{\mathrm{r}}$ proteins contain covalently bound sulphate.

The purple membrane is a specialized domain within the cell membrane of halobacteria. The purple membrane patches contain a retinal protein complex, bacteriorhodopsin, which makes up $75 \%$ of the total mass with lipid accounting for the remaining $25 \%$. Under growth conditions favourable for induction of purple membrane biogenesis, the purple membrane patches may cover more than $50 \%$ of the cell membrane area [1-3]. Thus bacterio-opsin is by far the most abundant membrane protein of halobacteria. In addition, bacterio-opsin represents a typical intrinsic membrane protein. According to the work of Henderson and Unwin [4], X-ray diffraction patterns of the membrane indicate that each bacterio-opsin molecule is composed of seven $\alpha$-helical segments, which extend perpendicular to the plane of the membrane for most of its width. These facts make the bacterio-opsin molecule an appealing model system for studying the various problems connected with the biosynthesis and integration of extremely hydrophobic membrane proteins. This paper describes characteristic features of bacterio-opsin biosynthesis. Evidence is also presented which shows the existence of protein species structurally related to bacterio-opsin.

Enzymes. Subtilisin (EC 3.4.21.14); DNAse (EC 3.1.4.5).

\section{MATERIALS AND METHODS}

\section{Strain and Culture Conditions}

Halobacterium halobium $\mathrm{R}_{1} \mathrm{M}_{1}$ [5] devoid of gas vacuoles and bacterioruberine was grown in peptone medium [6] in shake cultures at $40^{\circ} \mathrm{C}$. $500-\mathrm{ml}$ conical flasks containing $200 \mathrm{ml}$ peptone medium were inoculated with $4 \mathrm{ml}$ cell suspension (turbidity of about $1-1.5$ at $578 \mathrm{~nm}$ ) and were shaken with 100 reciprocating movements per min. Under these conditions, synthesis of bacteriorhodopsin is extensive after 3days growth.

\section{Pulse Labelling of Bacterio-opsin}

Cells ( $200 \mathrm{ml}$ of growth medium) grown for 3 days were collected by centrifugation and resuspended in $200 \mathrm{ml}$ of basal salt solution containing in $11250 \mathrm{~g}$ $\mathrm{NaCl}, 20 \mathrm{~g} \mathrm{MgSO}_{4} \cdot 7 \mathrm{H}_{2} \mathrm{O}, 2 \mathrm{~g} \mathrm{KCl}$ and, in addition, $0.5 \% \mathrm{~L}$-alanine. This cell suspension was shaken at $40^{\circ} \mathrm{C}$ for $3 \mathrm{~h}$ in order to exhaust the amino acid pools. $10 \mathrm{ml}$ of this cell suspension was centrifuged at $20000 \times \mathrm{g}$ for $3 \mathrm{~min}$ and the starved cells resuspended in $400 \mu \mathrm{l}$ (or $1000 \mu \mathrm{l}$ ) basal salt solution. The 25 -fold (or 10-fold) concentrated cell suspension was gently stirred in a test tube at $38^{\circ} \mathrm{C}$ and illuminated by a 
150-W slide projector (Rollei), with an OG 515 cut-off filter (Schott) at a light intensity of $100 \mathrm{~mW} / \mathrm{cm}^{2}$ at the position of the sample. After 5-min preincubation, a labelled amino acid (specific activity as indicated in the legends) was added. After the incubation, the cell suspension was chilled by adding basal salt solution cooled to $-20^{\circ} \mathrm{C}$. Cells were collected by centrifugation $\left(-10^{\circ} \mathrm{C}\right)$ and immediately lysed in $400 \mu \mathrm{l}$ water containing $10 \mathrm{mM} \mathrm{Mg}^{2+}$ and $10 \mu \mathrm{g} / \mathrm{ml}$ DNAse (Boehringer, Mannheim). In order to isolate the cell membrane fraction, the cell lysate was layered on a cushion of $3 \mathrm{ml} 20 \%$ sucrose in $50 \mathrm{mM}$ Tris- $\mathrm{HCl} \mathrm{pH} 7.5$. After centrifugation at $150000 \times g$ for $3 \mathrm{~h}$ the membrane fraction was present in the pellet.

\section{Sodium Dodecyl Sulphate/ \\ Polyacrylamide Gel Electrophoresis}

The gel system of Laemmli [7] was employed. A $12 \%$ acrylamide concentration was used throughout. After electrophoresis, the gels were prepared for fluorography as described by Bonner and Laskey [8]. The X-ray films were sensitized by pre-exposure with a light flash [9].

Apparent molecular weights were calculated using bacterio-opsin and chemically cross-linked dimers and trimers of bacterio-opsin [10] as molecular weight standards. Their molecular weights were assumed to be 26000,52000 and 78000 , respectively.

\section{Peptide Mapping}

Halobacteria were labelled with a radioactive amino acid as described above. The membrane fraction of these cells was dissolved in electrophoresis sample buffer and aliquots were subjected to electrophoresis on sodium dodecyl sulphate/polyacrylamide gels. After electrophoresis the gels were dried and the labelled proteins visualized by autoradiography. Bands of interest were cut out from the gel and the protein eluted by electrophoresis for $3 \mathrm{~h}$ into a dialysis bag. $50 \mu \mathrm{g}$ of unlabelled bacterio-opsin were added to an aliquot of the eluted radioactive protein and trichloroacetic acid was added to a final concentration of $20 \%$. The precipitate was collected on a Whatman $\mathrm{GF} / \mathrm{C}$ glass filter (diameter $10 \mathrm{~mm}$ ) and washed with $10 \%$ trichloroacetic acid. Delipidation was performed by washing first with acetone/ $\mathrm{NH}_{3}(5 / 1)$, then with acetone and finally with ethyl ether. The dried filter was then incubated in an Eppendorf cup with $40 \mu 1$ of protease solution $(2.5 \mu \mathrm{g}$ subtilisin in $0.1 \mathrm{M} \mathrm{N}$ methylmorpholine acetate $\mathrm{pH} 7.5$ ) at $37^{\circ} \mathrm{C}$ for $12 \mathrm{~h}$. Subtilisin, which readily digests bacterio-opsin (D. Mewes, personal communication) was used throughout. The digested protein was recovered from the glass filter by centrifugation and was lyophilized, redissolved in water and again lyophilized. Usually, more than $60 \%$ of the original radioactivity could be recovered in the digest. The digests were dissolved in $5-10 \mu \mathrm{l}$ chromatographic solvent. The samples were spotted on cellulose thin-layer plates $(20 \times 40 \mathrm{~cm}$, Polygram Cel 400, Macherey-Nagel) and developed in the first dimension with pyridine/1-butanol/water $(35 / 35 / 30$, $\mathrm{v} / \mathrm{v} / \mathrm{v}$ ). Development in the second dimension was performed by electrophoresis in water/acetic acid/pyridine $(834 / 60 / 6, \mathrm{v} / \mathrm{v} / \mathrm{v})$ for $50 \mathrm{~min}$ at $50 \mathrm{~V} / \mathrm{cm}$. Radioactive peptides were detected by fluorography as described by Randerath [12].

\section{Preparation of Spheroplasts}

Cells were starved for $6 \mathrm{~h}$ as described for the pulse labelling experiments. $10 \mathrm{ml}$ of the starved cell suspension was centrifuged and the cells were resuspended in $750 \mu \mathrm{l}$ salt solution containing no $\mathrm{Mg}^{2+}(250 \mathrm{~g}$ $\mathrm{NaCl}$ and $2 \mathrm{~g} \mathrm{KCl} / \mathrm{l})$. After the addition of $40 \mu \mathrm{l}$ $0.5 \mathrm{M}$ EDTA pH 7.5 the cell suspension was incubated at $37^{\circ} \mathrm{C}$ for $20 \mathrm{~min}$. Under these conditions, the rodshaped halobacteria are quantitatively converted to spheroplasts within 5-10 min, as checked by microscopic observation.

\section{Labelling of Bacterio-opsin with $\left[{ }^{35}\right.$ S $]$ Sulphate}

Cells ( $200 \mathrm{ml}$ growth medium) grown for $3-4$ days were collected by centrifugation and resuspended in a sulphate-free salt solution $\left(250 \mathrm{~g} \mathrm{NaCl}, 20 \mathrm{~g} \mathrm{MgCl}_{2}\right.$ and $2 \mathrm{~g} \mathrm{KCl} / 1)$. The cell suspension was shaken for $3 \mathrm{~h}$ at $40^{\circ} \mathrm{C}$ and the cells collected by centrifugation then resuspended 25 -fold concentrated in the sulphatefree salt solution. After the addition of $100 \mu \mathrm{Ci} / \mathrm{ml}$ carrier-free $\left[{ }^{35}\right.$ S $]$ sulphate (Amersham-Buchler, Braunschweig) the cell suspension was incubated under illumination for $2-10 \mathrm{~h}$ at $38^{\circ} \mathrm{C}$.

\section{RESULTS AND DISCUSSION}

Newly formed bacterio-opsin is initially found in the brown membrane fraction of the cell and can only 'crystallize' to form the purple membrane patches after reaction with retinal and a subsequent modification step $[13,14]$. Using the pulse-chase labelling technique it is possible to follow the kinetics of processing of newly synthesized bacterio-opsin within the cell membrane. In these experiments, halobacteria which actively synthesized purple membrane were labelled with $\left[{ }^{35}\right.$ S $]$ methionine for a few minutes. Immediately after labelling, the cells were lysed and the different membrane fragments separated by sucrose density gradient centrifugation. The distribution of $\left[{ }^{35} \mathrm{~S}\right]$ methionine-labelled membrane proteins was analyzed by sodium dodecyl sulphate/polyacrylamide gel electrophoresis.

Fig. 1 shows the results obtained. After a pulselabelling period as short as $120 \mathrm{~s}$ radioactive bacterio- 


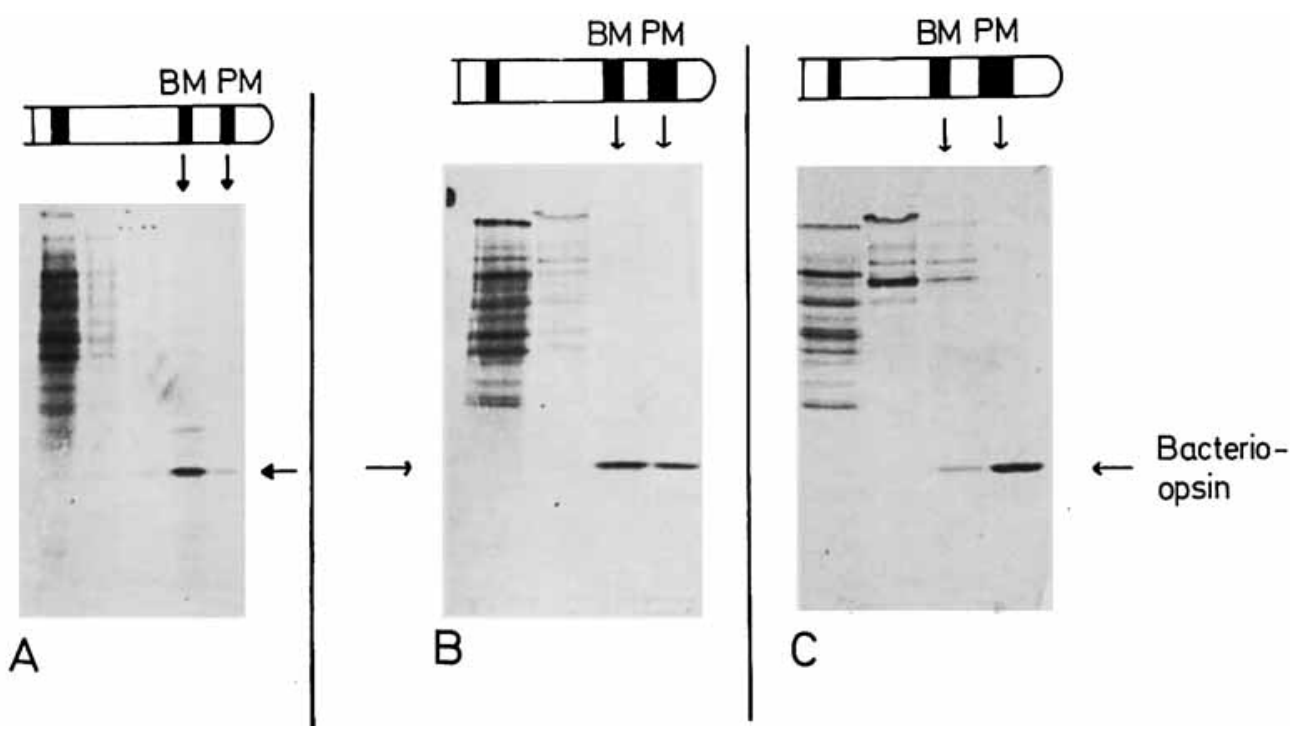

Fig. 1. Sodium dodecyl sulphate/polyacrylamide gel fluorograms of pulsed and pulse-chased proteins in different membrane fragments of halobacteria. Cells $(400 \mu \mathrm{l})$ were pulse labelled $(\mathrm{A}, \mathrm{B})$ and pulse-chase labelled $(\mathrm{C})$ as described in Materials and Methods $(40 \mu \mathrm{Ci}$ $\left[{ }^{35} \mathrm{~S}\right]$ methionine, $500 \mathrm{Ci} / \mathrm{mmol}$ ). The cell lysate was layered on a $20-45 \%$ sucrose density gradient and centrifuged at $250000 \times \mathrm{g}$ for $6 \mathrm{~h}$. Aliquots of the different membrane fractions (BM = brown membrane, PM = purple membrane) were applied to $12 \%$ slab gels. (A) Pulse labelling for $120 \mathrm{~s}$; (B) pulse labelling for $10 \mathrm{~min}$; (C) pulse labelling for $10 \mathrm{~min}$, followed by a 20 -min chase

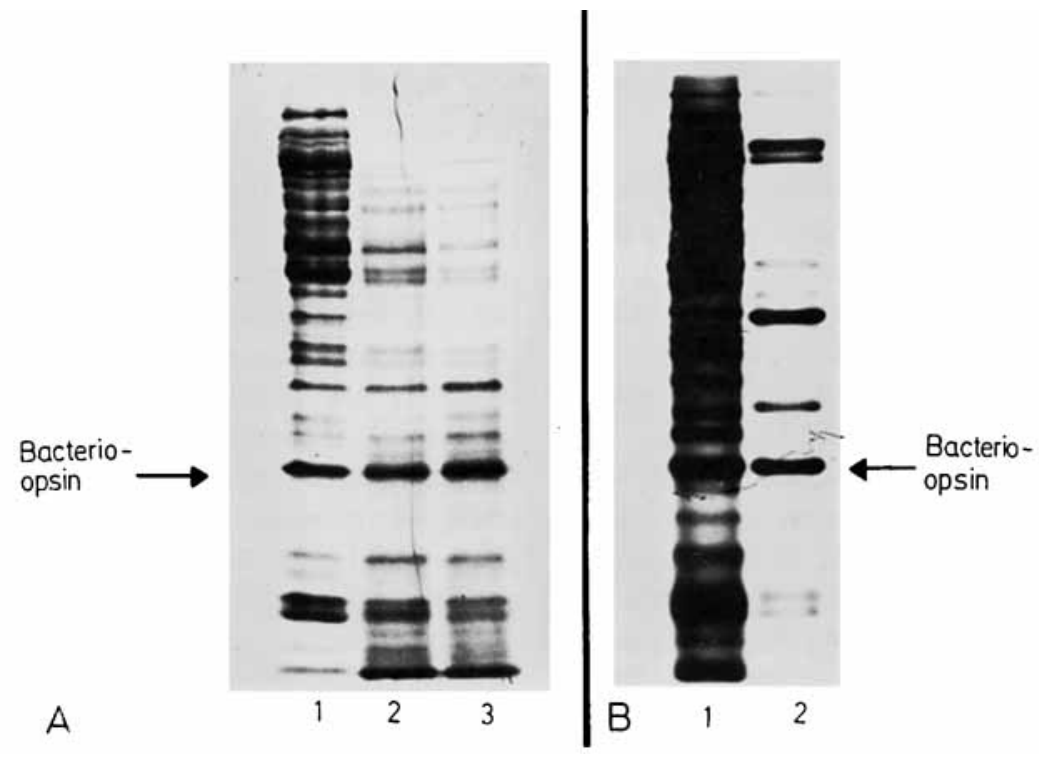

Fig.2. Sodium dodecyl sulphate/polyacrylamide gel fluorograms of cell lysates from halobacteria pulse labelled in the presence or absence of RNA-synthesis inhibitors. (A) Cells were pulse labelled $(400 \mu \mathrm{l}$ cell suspension, concentrated 25-fold, see Materials and Methods) with $15 \mu \mathrm{Ci} \mathrm{L}-\left[{ }^{35} \mathrm{~S}\right]$ methionine $(500 \mathrm{Ci} / \mathrm{mmol})$ for $15 \mathrm{~min}$ at $37^{\circ} \mathrm{C}$. (1) Pulse labelling in the absence of an inhibitor. (2) Rifamycin SV (150 $\left.\mu \mathrm{g} / \mathrm{ml}\right)$ was added to the cell suspension at zero time. (3) Rifamycin SV (150 $\mu \mathrm{g} / \mathrm{ml})$ was added to the cell suspension 15 min prior to pulse labelling. (B) Cells were pulse labelled as described for (A). (1) Pulse labelling in the absence of an inhibitor. (2) Ethidium bromide (100 $\mu \mathrm{g} / \mathrm{ml}) \mathrm{was}$ added to the cell suspension $15 \mathrm{~min}$ prior to pulse labelling

opsin is already detectable in the cell membrane. However, most of the newly synthesized bacterioopsin is found in the brown membrane fraction, only trace amounts are found in the purple membrane fraction. After a labelling period of $10 \mathrm{~min}$, some of the newly synthesized bacterio-opsin molecules can be detected in the purple membrane. After a 20-min chase with unlabelled methionine most of the labelled bacterio-opsin has been processed from the non-crystalline state within the brown membrane to the crystalline state within the purple membrane.

\section{The Effects of RNA-Synthesis Inhibitors}

Pulse-labelling experiments in the presence of the RNA-synthesis inhibitor rifampicin demonstrate that the synthesis of bacterio-opsin is unusually resistant to this drug (Fig. 2A). The opsin production is much 

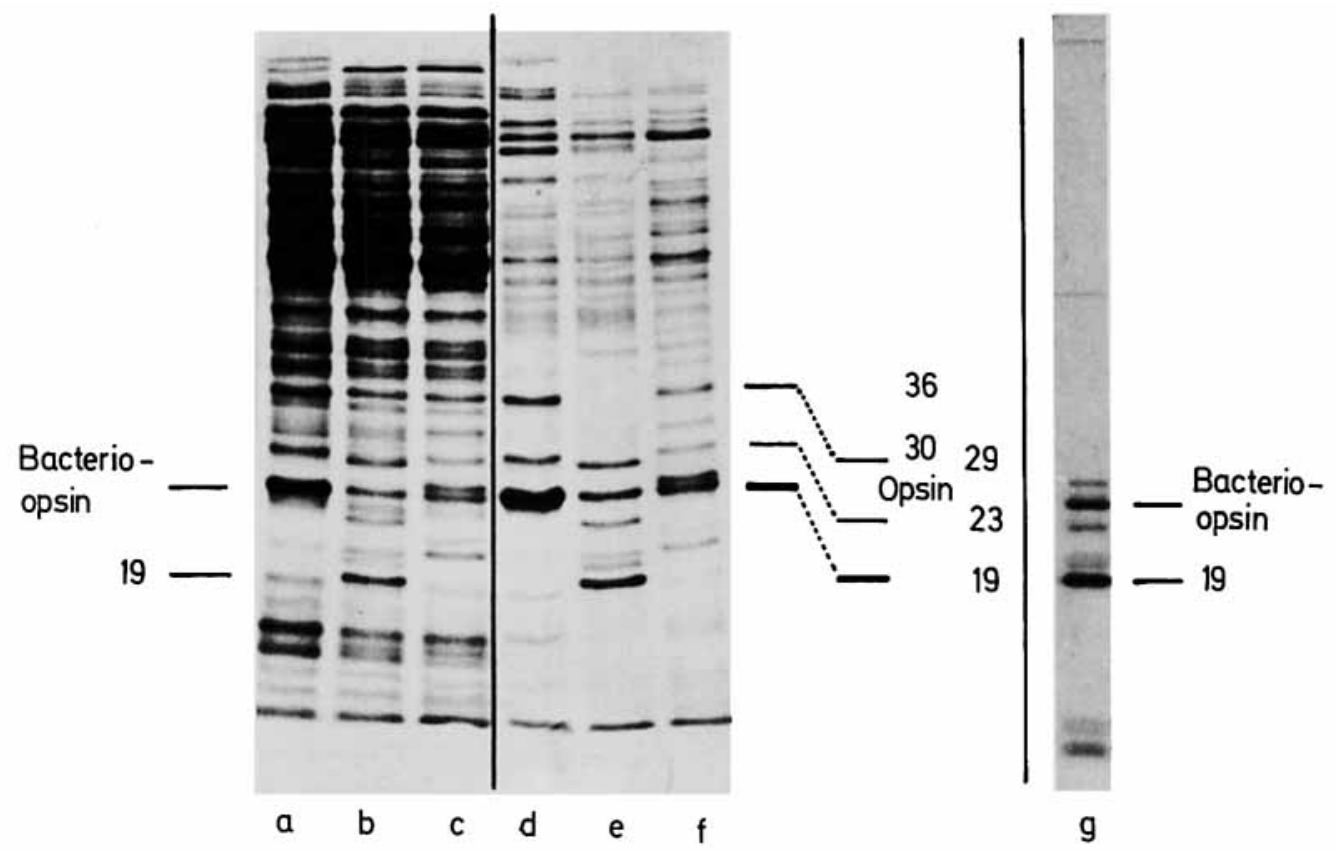

Fig. 3. Sodium dodecyl sulphate/polyacrylamide gel fluorograms of proteins synthesized in halobacteria before and after conversion to spheroplasts. Pulse labelling ( $20 \mathrm{~min}, 15 \mu \mathrm{Ci}\left[{ }^{35} \mathrm{~S}\right] \mathrm{methionine,} 500 \mathrm{Ci} / \mathrm{mmol}$ ) and the preparation of spheroplasts were performed as described in Materials and Methods. (a) Protein pattern of rod-shaped halobacteria; (b) protein pattern of spheroplasts; (c) protein pattern of spheroplasts after readjustment of the $\mathrm{Mg}^{2+}$ concentration to $50 \mathrm{mM}$; (d, e, f) protein pattern of the isolated membrane fraction of a, b and c, respectively; (g) the purple membrane fraction of spheroplasts. Numbers refer to $M_{\mathrm{r}} \times 10^{3}$

more resistant to rifampicin than is the synthesis of most of the other cell proteins. Ethidium bromide, a drug which is also known to interfere with RNA synthesis [15-17], is found to act even more selectively in halobacterial protein synthesis. Fig. $2 \mathrm{~B}$ shows the result of a pulse-labelling experiment in the presence or absence of ethidium bromide. Even though a total cell lysate was applied to the sodium dodecyl sulphate/ polyacrylamide gel, synthesis of only five main protein species remains essentially unaffected in the presence of the drug. Interestingly, all the species are membranebound proteins, one of which is bacterio-opsin. Bacterio-opsin continues to be synthesized for more than 60 min after the addition of ethidium bromide (data not shown).

These experiments indicate that a specialized type of protein synthesis is operative in bacterio-opsin production. An unusually long lifetime of the mRNA coding for bacterio-opsin may be a reason for the drug resistance. Inouye and co-workers [18] clearly demonstrated the stabilities of the mRNAs which code for the envelope proteins of Escherichia coli. It would thus seem that a high stability of mRNA is a common feature of bacterial membrane protein biosynthesis.

\section{Selective Disturbance \\ of Bacterio-opsin Biosynthesis}

By definition, at least one step of membrane protein processing has to take place at or in the membrane.
Therefore any disturbance of membrane structure is likely to interfere with membrane protein biosynthesis or processing. It is very easy to disturb the membrane structure of halobacteria. Simply by lowering the $\mathrm{Mg}^{2+}$ ion concentration in the medium, the rod-shaped halobacteria are converted to spheroplasts. The altered geometry of the cell as well as the changed ionic environment most probably disturb the membrane structure. The products of protein synthesis in halobacteria before and after conversion to spheroplasts are shown in Fig. 3. While the synthesis of nearly all detectable cell proteins remains unaffected in spheroplasts, much less radioactivity is found in the band corresponding to bacterio-opsin. Instead a new radioactive band with a lower apparent molecular weight (19000) emerges. Interestingly, this new protein species is found to be present in the purple membrane fraction isolated from the spheroplasts (Fig. $3 \mathrm{~g}$ ). This suggests that this $19000-M_{\mathrm{r}}$ protein is structurally related to bacterio-opsin. Evidence for this is provided by peptide mapping as shown in Fig. 4. In these experiments spheroplasts were labelled with $\left[{ }^{3} \mathrm{H}\right]$ lysine and $\left[{ }^{35} \mathrm{~S}\right]$ methionine, respectively. After sodium dodecyl sulphate/polyacrylamide gel electrophoresis of the membrane fraction, the $19000-\mathrm{M}_{\mathrm{r}}$ protein was eluted from the gel and digested by incubation with subtilisin. In Fig. 4 the resulting peptide maps of the 19000- $M_{\mathrm{r}}$ protein are compared with the corresponding maps of authentic bacterio-opsin. All $\left[{ }^{3} \mathrm{H}\right]$ lysine-containing peptides of bacterio-opsin and most of the $\left[{ }^{35} \mathrm{~S}\right]$ - 


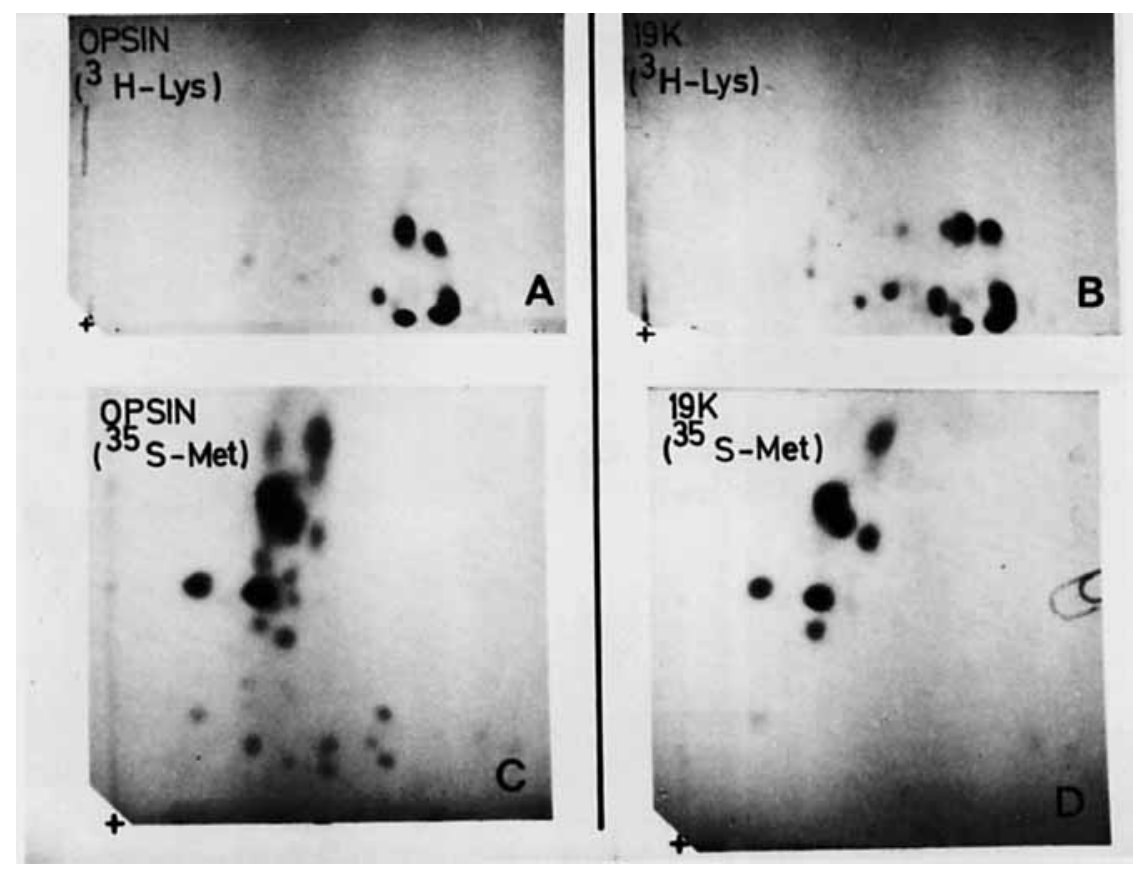

Fig. 4. Peptide maps of $\left[^{35} \mathrm{~S} /\right.$ methionine-labelled or $\left[^{3}\right.$ H]lysine-labelled bacterio-opsin and 19000-Mr protein. Subtilisin digests of bacterioopsin and $19000-M_{\mathrm{r}}$ protein were prepared and analyzed by two-dimensional separation on cellulose thin-layer plates as described in Materials and Methods. Electrophoresis at pH 3.5 was towards the cathode, i.e. from left to right. Labelled peptides were visualized by fluorography. The small cross at the lower left hand corner of each chromatogram marks the origin. (A) $\left[{ }^{3} \mathrm{H}\right]$ Lysine-labelled bacterio-opsin; (B) $\left[{ }^{3} \mathrm{H}\right] \mathrm{lysine}$ labelled 19000- $M_{\mathrm{r}}$ protein; (C) ${ }^{35}$ S]methionine-labelled bacterio-opsin; (D) ${ }^{35}$ S]methionine-labelled $19000-M_{\mathrm{r}}$ protein

methionine-containing peptides of bacterio-opsin are also found to be present in the map of the $19000-M_{\mathrm{r}}$ protein. These results indicate that this protein is structurally related to bacterio-opsin. It remains to be established whether the shift in the apparent molecular weight is caused by premature chain termination in bacterio-opsin biosynthesis or by a wrong proteolytic processing of a hypothetical bacterio-opsin precursor. Alternatively, the shift of the apparent molecular weight could be caused by different degrees of posttranslational modifications (e.g. glycosylation or by sulphate ester formation, see below).

In spheroplasts, the production of intact bacterioopsin can partly be re-established if the $\mathrm{Mg}^{2+}$ concentration is readjusted to normal values $(50-$ $150 \mathrm{mM}$, see Fig. $3 \mathrm{c}$ ). In addition to bacterio-opsin, a slightly heavier protein species (corresponding to about 15 additional amino acid residues) emerges. This additional protein species is again structurally related to bacterio-opsin (peptide maps not shown).

The purple membrane fraction of pulse-labelled spheroplasts (Fig. 3 g) contains, besides the 19000- $M_{\text {r }}$ protein, two more protein species with apparent molecular weights of 23000 and 29000 ; it is possible that these two species are structurally related to bacterio-opsin. The appearance of these two proteins is accompanied by the disappearance of a $30000-M_{\mathrm{r}}$ and a $36000-M_{\mathrm{r}}$ protein present in the membrane of rod-shaped halobacteria (Fig. $3 \mathrm{~d}$ and e). This suggests that the membrane protein pattern in spheroblasts (Fig. 3e) arises by a 7000 shift of the apparent molecular weights of bacterio-opsin, of the $30000-M_{\mathrm{r}}$ protein and of the $36000-M_{\mathrm{r}}$ protein. The two latter proteins were characterized in more detail by proteolytic cleavage and peptide mapping; the proteins, labelled with $\left[{ }^{3} \mathrm{H}\right]$ lysine or $\left[{ }^{3} \mathrm{H}\right]$ tyrosine, were purified by preparative sodium dodecyl sulphate/polyacrylamide gel electrophoresis and digested by subtilisin. The peptide maps shown in Fig. 5 demonstrate that all lysine-containing peptides from bacterio-opsin are also present in the $30000-M_{\mathrm{r}}$ protein. With two exceptions this is also true for the $36000-M_{\mathrm{r}}$ protein map. A control map obtained from a 1:1:1 mixture of the peptides of bacterio-opsin, the 30000- $M_{\mathrm{r}}$ protein and the $36000-M_{\mathrm{r}}$ protein did not show any additional spots. The main $\left[{ }^{3} \mathrm{H}\right]$ tyrosine-containing peptides obtained from bacterio-opsin had a common identity in four out of five cases with the peptides obtained from the $30000-M_{\mathrm{r}}$ and the $36000-M_{\mathrm{r}}$ proteins. We therefore conclude that these two proteins and bacterio-opsin share common amino acid sequences. Surprisingly, no additional $\left[{ }^{3} \mathrm{H}\right]$ lysine-containing peptides are found in the maps of the $30000-M_{\mathrm{r}}$ and the $36000-M_{\mathrm{r}}$ proteins. It therefore appears unlikely that the higher apparent molecular weights are due to an elongated bacterio-opsin polypeptide chain. More likely, as yet unknown post-translational modifications may cause the differences in the electrophoretic mobilities. 


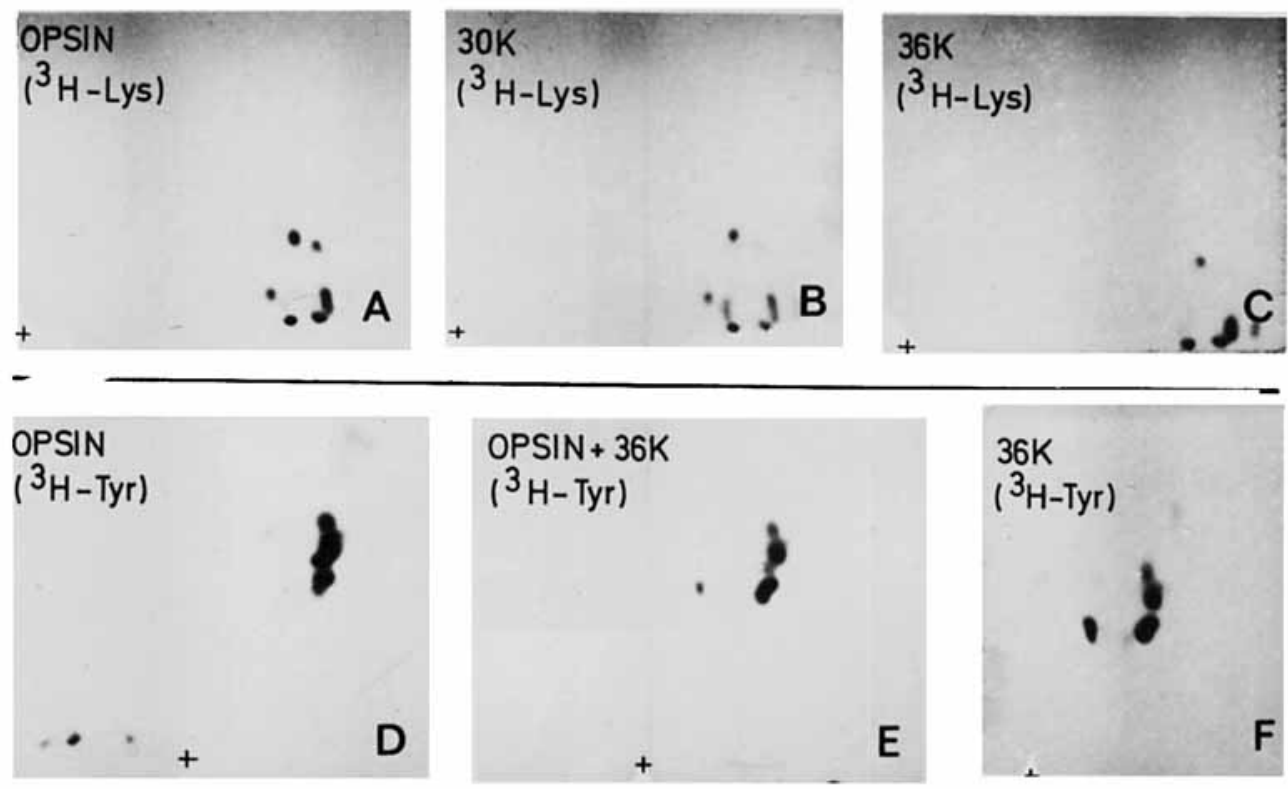

Fig. 5. Peptide maps of $36000-M_{r}$ protein, $30000-\mathrm{M}_{r}$ protein and bacterio-opsin labelled with $\left[{ }^{3} \mathrm{H}\right]$ lysine or $\left./{ }^{3} \mathrm{H}\right]$ tyrosine. Pulse labelling $(60$ min, $100 \mu \mathrm{Ci} \mathrm{L}-\left[4,5-{ }^{3} \mathrm{H}_{2}\right]$ lysine or $\mathrm{L}-\left[3,5-{ }^{3} \mathrm{H}_{2}\right]$ tyrosine, $\left.50 \mathrm{Ci} / \mathrm{mmol}\right)$ and the preparation of subtilisin digests were performed as described in Materials and Methods. Electrophoresis as in Fig. 4. (A, B, C) [ $\left.{ }^{3} \mathrm{H}\right]$ Lysine-labelled bacterio-opsin (A), 30000- $M_{\mathrm{r}}$ protein (B) and 36000- $M_{\mathrm{r}}$ protein (C); (D, E, F) $\left[{ }^{3} \mathrm{H}\right]$ tyrosine-labelled bacterio-opsin (D), bacterio-opsin and $36000-M_{\mathrm{r}}$ protein $(\mathrm{E})$ and $36000-M_{\mathrm{r}}$ protein $(\mathrm{F})$

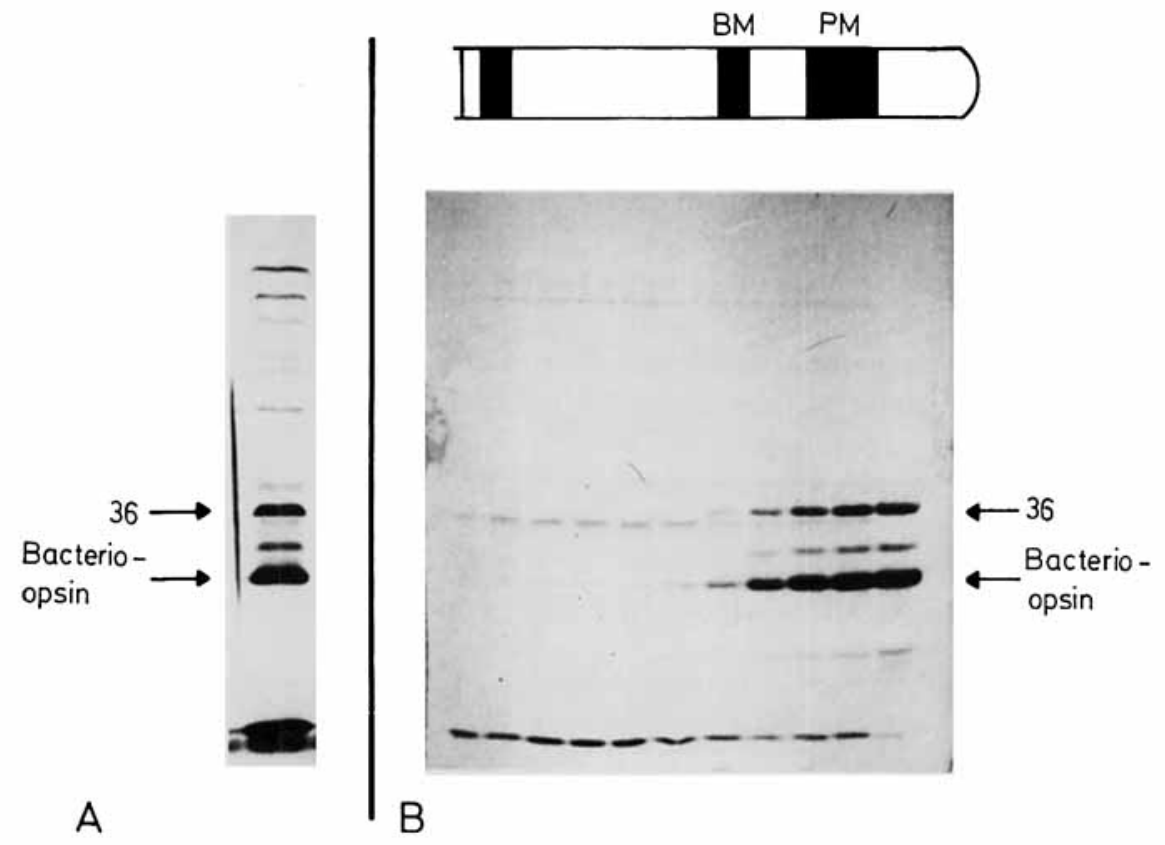

Fig. 6. Sodium dodecyl sulphate/polyacrylamide gel fluorograms of a homogenate and of membrane fractions from halobacteria pulse labelled with $\left[{ }^{35}\right.$ S $]$ sulphate. $\left[{ }^{35}\right.$ S]Sulphate labelling was performed as described in Materials and Methods. (A) Cell homogenate; (B) aliquots of the different membrane fractions obtained by sucrose density gradient centrifugation were applied to a $12 \%$ slab gel. BM = brown membrane; $\mathrm{PM}=$ purple membrane; 36 refers to the position of the $36000-M_{\mathrm{r}}$ protein

The 30000-M, Protein, 36000-Mr Protein and Bacterio-opsin Contain Covalently Bound Sulphate

The relationship between these three proteins is further documented by the observation that it is exactly these proteins which become selectively labelled when halobacteria are incubated with $\left[{ }^{35}\right.$ S $]$ sulphate. As shown in Fig. 6A, only three proteins of the total cell lysate become highly labelled; their electrophoretic mobilities are identical with that of bacterio-opsin, the $30000-M_{\mathrm{r}}$ protein and the $36000-M_{\mathrm{r}}$ protein, respectively. In addition, these $\left[{ }^{35} \mathrm{~S}\right]$ sulphate-labelled proteins are incorporated in the purple membrane fraction, as revealed by the membrane fractionation shown in Fig. 6B. This strongly suggests their identity with bacterio-opsin, the $30000-M_{\mathrm{r}}$ protein and the 


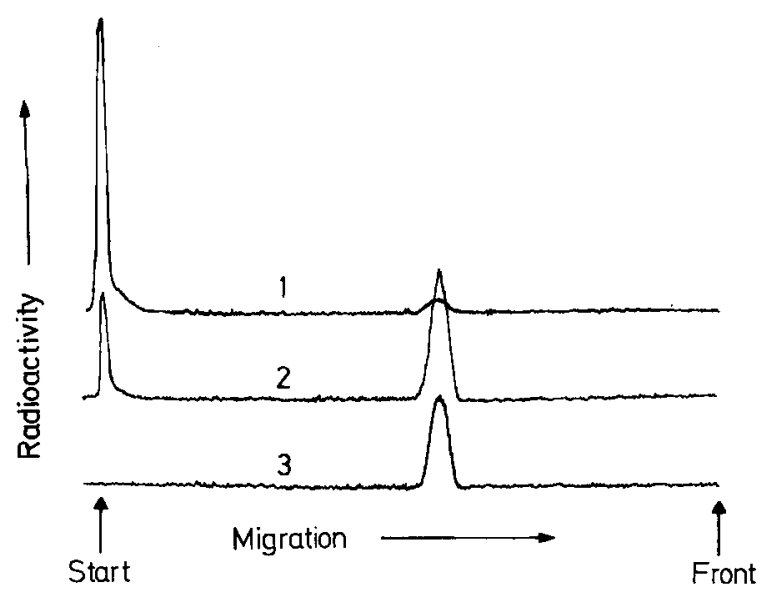

Fig. 7. Hydrolysis of $I^{35} S /$ sulphate-labelled bacterio-opsin. Densitometric tracings of an autoradiogram obtained after poly(ethylenimine)-cellulose thin-layer chromatography in $0.25 \mathrm{M} \mathrm{NH}_{4} \mathrm{HCO}_{3}$. (1) Acid hydrolysis in $0.01 \mathrm{M} \mathrm{HCl}$ for $10 \mathrm{~min}$ at $90^{\circ} \mathrm{C}$; (2) acid hydrolysis in $0.05 \mathrm{M} \mathrm{HCl}$ for $60 \mathrm{~min}$ at $90{ }^{\circ} \mathrm{C}$; (3) $\left[{ }^{35} \mathrm{~S}\right]$ sulphate standard

$36000-M_{\mathrm{r}}$ protein. The following evidence can be offered for the covalent linkage of sulphate.

a) The $\left[{ }^{35} \mathrm{~S}\right]$ sulphate-labelled proteins purified by sodium dodecyl sulphate/polyacrylamide gel electrophoresis do not lose the label when precipitated by $10 \%$ trichloroacetic acid followed by extensive delipidization with acetone/ $\mathrm{NH}_{3}(5 / 1)$, acetone and ethyl ether.

b) Treatment of $\left[{ }^{35} \mathrm{~S}\right]$ sulphate-labelled bacterioopsin with $0.05 \mathrm{M} \mathrm{HCl}$ at $90^{\circ} \mathrm{C}$ for 60 min liberates $\left[{ }^{35} \mathrm{~S}\right]$ sulphate as shown by poly(ethyleneimine)-cellulose chromatography (Fig. 7).

c) Addition of the sulphur-containing amino acids cysteine and methionine to the cell suspension during the labelling period does not depress the incorporation of radioactivity into bacterio-opsin, the $30000-M_{\mathrm{r}}$ and $36000-M_{\mathrm{r}}$ proteins.

d) Digestion of $\left[{ }^{35} \mathrm{~S}\right]$ sulphate-labelled bacterioopsin with subtilisin liberates water-soluble compounds which are negatively charged at $\mathrm{pH} 3.5$, as revealed by peptide mapping (not shown).

Interestingly, the peptide map of $\left[{ }^{3} \mathrm{H}\right]$ tyrosinelabelled bacterio-opsin also shows negatively charged peptides at pH 3.5 (Fig. 5). Moreover, these peptides migrate to identical positions as do the $\left[{ }^{35}\right.$ S $]$ sulphatelabelled digestion products. Clearly, more analytical work is necessary to establish the chemical nature of this sulphate linkage. The presence of these $\left[{ }^{35} \mathrm{~S}\right]$ sulphate-containing $30000-M_{\mathrm{r}}$ and $36000-M_{\mathrm{r}}$ proteins in the purple membrane fraction is completely unexpected; sodium dodecyl sulphate/polyacrylamide electrophoresis patterns of purple membrane obtained by conventional staining with Coomassie blue do not show any protein components with these molecular weights. The biological function of the two proteins is as yet unknown. A possible function as a bacterioopsin precursor could not be substantiated. In pulsechase experiments the two proteins did not turn over significantly. Possibly, the negatively charged sulphate groups present on these proteins and on bacteriorhodopsin could be involved in the mechanism of proton conductance or proton pumping. schaft

This work was supported by the Deutsche Forschungsgemein-

\section{REFERENCES}

1. Oesterhelt, D. \& Stoeckenius, W. (1971) Nat. New Biol. 233, $149-152$.

2. Blaurock, A. E. \& Stoeckenius, W. (1971) Nat. New Biol. 233, $152-154$.

3. Ocsterhelt, D. \& Stoeckenius, W. (1973) Proc. Natl Acad. Sci. U.S.A. 70, 2853-2857.

4. Henderson, R., \& Unwin, P. N. T. (1975) Nature (Lond.) 257 , $28-32$.

5. Milanytch, M. (1973) Diplomarbeit, Universität München.

6. Oesterhelt, D. \& Stoeckenius, W. (1974) Methods Enzymol. 3I, $667-678$.

7. Laemmli, U. K. (1970) Nature (Lond.) 227, 680-685.

8. Bonner, W. M. \& Laskey, R. A. (1974) Eur. J. Biochem. 46, $83-88$.

9. Laskey, R. A. \& Mills, A. D. (1975) Eur. J. Biochem. 56, 335341.

10. Dellweg, H. G. \& Sumper, M. (1978) FEBS Lett. 90, 123-126.

11. Reference deleted.

12. Randerath, K. (1970) Anal. Biochem. 34, $188-205$.

13. Sumper, M., Reitmeier, H. \& Oesterhelt, D. (1976) Angew. Chem. Int. Ed. Engl. 15, 187-194.

14. Sumper, M. \& Herrmann, G. (1976) FEBS Lett. 69, 149-152.

15. South, D. J. \& Mahler, H. R. (1968) Nature (Lond.) 218, $1226-1232$

16. Fukuhara, H. \& Kujawa, C. (1970) Biochem. Biophys. Res. Commun. 41, 1002-1008.

17. Richardson, J. P. (1973) J. Mol. Biol. 78, 703-714.

18. Inouye, M. (1975) in Membrane Biogenesis (Tzagoloff, A., ed.) pp. $351-391$, Plenum Press, New York.

M. Sumper, Institut für Biochemie, Fachbereich Biologie und Vorklinische Medizin der Universität Regensburg,

Universitätsstraße 31, D-8400 Regensburg, Federal Republic of Germany

G. Herrmann, Institut für Biochemie der Julius-Maximilians-Universität Würzburg,

Röntgenring 11, D-8700 Würzburg, Federal Republic of Germany 